\title{
Ritucharaya - Ayurvedic Way for Healthy Living
}

\section{Opinion}

The body which we have received from the god is a natural gift, precious but also very sensitive. It gets affected by all the things around it, the environment where it lives, the things it touch, the food intake, the things it see \& feels and so on. Similarly, our body also gets affected by various seasons. There are total six seasons (Ritus) according to the Ayurveda in one year \& the body needs to adapt itself according to the seasonal variation to remain healthy, fit \& disease free. It is because the body of every person is unique according to the Ayurveda in terms of their Prakriti \& doshas effects. The body consists of 3 types of Doshas (Vata, Pitta \& Kapha) \& 3 types of Gunas (Satvik, Rajsik \& Tamsik) in different quantity. These components are very important \& have so much effect not just on one's behavior but also one's likings \& disliking, type of skin we get, the food we eat, digestion process, body's adaptation to different situations \& seasons, kind of diseases which are likely to attack our type of body etc.

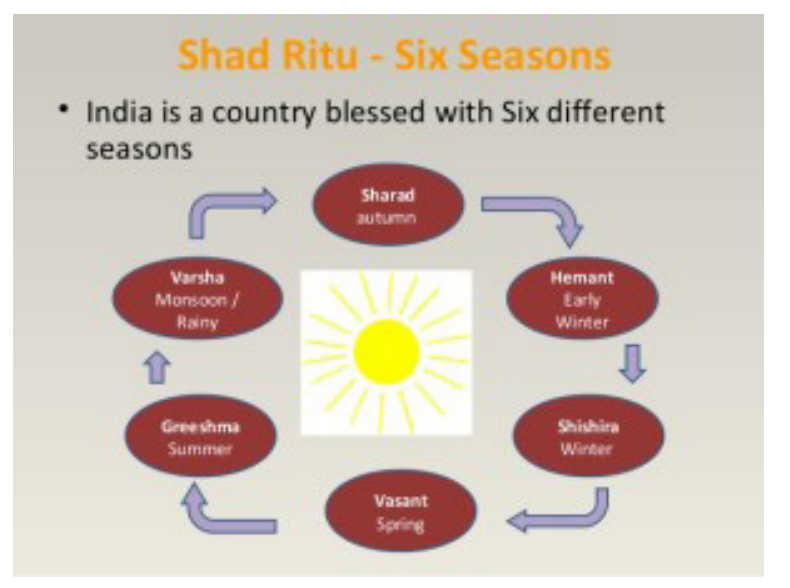

Ayurveda, being a complete science is a kind of natural helpline for human beings to know about their body type \& live accordingly so as to avoid unnecessary health issues. One can also say it as an art of healthy living as it gives complete knowledge about our body \& guides us as to what kind of food we should eat at what time, the type of lifestyle we must follow, the correct timing of taking food \& sleep, correct posture of sleeping, things we should avoid to eliminate risk factor associated with our health \& behavior both and so on. And all this is required to maintain hormonal balance inside the body In the present time, we spend a lot of our hard earned money on medicines \& treatments of not just chronic health issues but for very minor problems like indigestion, mental stress, sleeplessness which if not treated properly can be converted into serious problems.

\section{About Ritucharya}

Ritu means season \& charya means following or discipline. Ritucharya in simple words means seasonal routine, the lifestyle \& diet that need to be followed according to the particular seasonal requirement to maintain hormonal balance in our body \& to be fit

Conceptual Paper
Volume 10 Issue 3 - 2017
Baldeep Kour*
Rajiv Gandhi University of Health Sciences, India
*Corresponding author: Baldeep Kour, Co-Founder \&
Medical Director of Deep Ayurveda, Rajiv Gandhi University
of Health Sciences, India, Email: info@deepayurveda.com
Received: November 10, 2016 | Published: December 29,
2017

and healthy. Ayurveda divides the whole year into two kaals on the basis of position of the sun:

\section{A. Aadaan Kaal (Uttarayan) \& \\ B. Viserga Kaal (Dakshinayaan).}

During Uttarayan, sun \& wind are powerful which takes away the people strength \& cooling qualities of earth. During Dakshinayaan, sun releases the strength, moon is more powerful $\&$ earth regains its coolness through clouds, rain \& cold winds. The six weathers are also the part of these kaals as summer, Spring \& Cold seasons forms the Uttrayan Kaal \& Rainy, Autumn \& Winter season forms the Dakshinayaan Kaal. In context to our body, these two kaals affects the Doshas in our body in the following way:

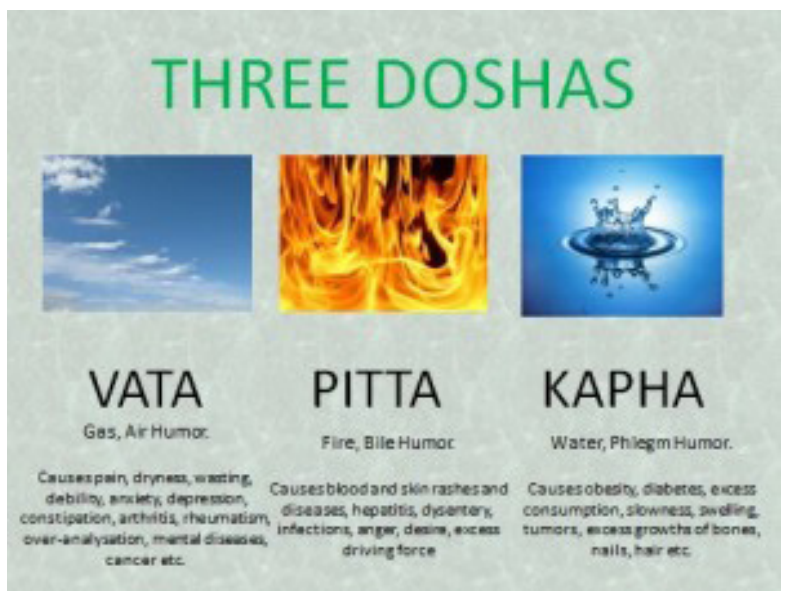

a. Vata dosha accumulates during the dry/ dehydrating heat of the summer. Rainy season makes it aggravated which causes indigestion, acidic atmosphere $\&$ gas produced from the earth.

b. Pitta accumulates during the rainy season due to indigestion \& acidic atmosphere. Autumn makes it aggravated when heat returns after the cooling spell of the rainy season.

c. Kapha accumulates during the cold season due to winds, 
clouds \& rain generated coolness. Spring season makes it aggravated when warm weather liquefies the accumulating Kapha.
The six seasons along with their properties are shown as below:

\begin{tabular}{|c|c|c|c|c|c|c|}
\hline Kaal (Semester) & $\begin{array}{c}\text { Ritu } \\
\text { (Season) }\end{array}$ & Maas (Month) & $\begin{array}{l}\text { Properties of } \\
\text { the Season }\end{array}$ & Powerful Tastes & $\begin{array}{l}\text { Dosha } \\
\text { Prevelent }\end{array}$ & Required Panchkarma \\
\hline \multirow{3}{*}{$\begin{array}{l}\text { Aadaan } \\
\text { (Northeren } \\
\text { Solastice) }\end{array}$} & Sishira & $\begin{array}{l}\text { Magha and Phalguna (mid } \\
\text { January to mid march) }\end{array}$ & $\begin{array}{l}\text { Cold and dewy } \\
\text { season }\end{array}$ & Tikta (bitter) & Pitta & $\begin{array}{l}\text { Swedana, Patar Potli, } \\
\text { Shashti shali Pind } \\
\text { Swedan, Abhyangam }\end{array}$ \\
\hline & Vasanta & $\begin{array}{l}\text { Chaitra and Baisakh (mid } \\
\text { March to mid May) }\end{array}$ & Spring season & $\begin{array}{c}\text { Kashaya } \\
\text { (astringent) }\end{array}$ & Kapha & Vaman \\
\hline & Grishma & $\begin{array}{l}\text { Jyeshtha and Aashadha } \\
\text { (mid May to mid July) }\end{array}$ & Summer season & Kattu & Vata & $\begin{array}{l}\text { Mild Abhyangam \& } \\
\text { Swedana }\end{array}$ \\
\hline \multirow{3}{*}{$\begin{array}{c}\text { Visarga (Southern } \\
\text { Solastice) }\end{array}$} & Varsha & $\begin{array}{l}\text { Shravan and Bhadrapada } \\
\text { (mid July to mid } \\
\text { September) }\end{array}$ & Rainy season & Amala (sour) & Vata & Vasti Karam \\
\hline & Sharad & $\begin{array}{l}\text { Aashvin and Kartika } \\
\text { (mid September to mid } \\
\text { November) }\end{array}$ & Autumn season & Lavan (salty) & Pitta & Virechan \\
\hline & Hemant & $\begin{array}{l}\text { Margshirsha and Pausha } \\
\text { (mid November to mid } \\
\text { January) }\end{array}$ & Winter season & Madhura (sweet) & Pitta & $\begin{array}{l}\text { Virechan, Abhyangam, } \\
\text { Swedan }\end{array}$ \\
\hline
\end{tabular}

So, the above table shows that how minutely a season affects our body. It is clearly mentioned in our sacred Atharva Veda also as shown above.

\section{How the lifestyle must be modified according to the seasons is explained as below}

a. Hemanta ritucharya: During this season, people gain strength, having powerful digestive fire, because it gets obstructed from flowing outward due to external winter. One should consume food predominant with sweet sour and salt tastes. A person feels hungry early in the morning due to longer nights. So, after attending to ablutions, one should resort to Abhaynga (oil massage) especially on scalp and forehead with oils that have Vata balancing properties. Mild massage of the body is recommended. After this, oil is washed off with astringent powders and bathing. Some aromatic herbs are used like Gulab Pattar in this. The body is exposed to the fumes of aguru (Aquilaria agallocha). Food prepared with wheat flour, black gram products of sugarcane and of milk, food prepared from freshly harvested corn, muscles, fat and edible oils should be partaken as food. Warm water should be used for oblutions, thick sheet made of cotton, leather, silk, wool or bark of trees that are light in weight should be used during sleep. Exposure to sunlight and fire should be resorted to, judiciously. Foot wear should be worn always. Persons who spend their time residing in houses kept warm by fire, in inner most apartment encircled with others, or in underground chambers, will not be affected by diseases due to cold and dryness. Overall, in Hemantha Ritu, the strength and digestion power are more. Hence one can exercise, undergo oil massage, eat heavy foods and may have sex.

b. Recommended Ayurvedic medicines: Livclear Herbal powder, Livclear capsules, Livclear syrup, Respocare Herbal Powder, Respocare syrup, Nervocare capsules, Ayurvit capsules, Arthro-rid capsules, Body massage oil \& Joint Pain Oil.

c. Sisira Ritucharya: Even in shishira Ritu, the above regimen should be adopted with more intensity as there is severe cold and more dryness in this season.

d. Recommended Ayurvedic medicines: Livclear Herbal powder, Livclear capsules, Livclear syrup, Respocare Herbal Powder, Respocare syrup, Talishadi Churan \& Sitopladi Churan.

\section{Vasanta ritucharya}

Kapha which was increased in Shishira (cold season) becomes liquefied by the heat of the Sun in Vasanta (spring). It diminishes the digestive fire (Agni) and gives rise to many diseases because of which Kapha should be controlled quickly, by resorting to strong emesis therapy (Vamana Panchakarma procedure), Nasya (nasal medication) and other therapies. In order to balance the Kapha, avoid hard to-digest, cold, fatty, sour \& sweet food along with sleeping during day time. Food should also be chosen to mitigate Kapha, which is easily digestible and dry (moisture-free, fatfree). Physical exercises, dry massage and little physical work out should be done. The person should take bath along with the paste of karpura (camphor), chandan (sandalwood), aguru (Aquilaria agallocha), and kumkuma (saffron).

Have one year old barley, wheat and honey as food; Drink the juice of mango fruit mixed with fragrant substances, in the company of friends, thereby producing satisfaction. Beverages can be taken such as asava \& sidhu (fermented infusion), arista (fermented decoction), mardvika (fermented grape juice), or sarambu (extract of trees such as asana, chandan etc.) or water mixed with honey, or water boiled with jalada (musta - Nut grass). 
The main thing to be noted here is that Vasant is the period of Ritusandhi when the weather changes. It becomes necessary for our body to adopt itself to the new conditions. That's why Hindu Navratras \& even Muslim's Rmzan comes during this period and fasting is done. Scientific reason behind it is that body needs detoxification \& cleansing this time. Pitta reduces which weakens the body's appetite and body can digest only light food.

Recommended ayurvedic medicines: Livclear Herbal powder, Livclear capsules, Livclear syrup, Respocare Herbal Powder, Respocare syrup, Nervocare capsules, Ayurvit capsules \& Triyog herbal powder and capsules.

Recommended panchkarma therapies: Vaman, Nasyam, Dhoompan, Steam bath along with Abhyangam.

Greeshma ritucharya: In Greeshma (summer) the sun rays become powerful and appear to be destructive. Kapha slowly decreases and in turn Vata starts increasing, hence avoid use of salt, pungent and sour foods, heavy physical exercises and exposure to sunlight, during this season. Wrong thing which people do during this period is the poor diet and intake of more cold water in its place which not just weakens the body but also lowers the digestive agni which in turn causes digestion related disorders. Water should be taken at room temperature. Antioxident food items must also be taken so maintain good appetite \& health. Food which are sweet, light (easy to digest), fatty, cold and liquid should be taken, take corn flour mixed with cold water and sugar after taking bath in cold water. Madya (wine) is strictly avoided during this period. If very necessary, taken in very little quantity or diluted with more quantity of water; If wine is taken in large doses, it will cause inflammatory conditions, it will make the body fragile and weak, increases burning sensation and causes delusion. During summer, boiled rice, which is white in colour, (like full moon) should be eaten along with Moong daal khichdi, green vegetables like cucumber, Tinday, Pumpkin \& other mineral rich food that are easy to digest. Various soups, juices, nuts, dry fruits and other liquid items must be eaten which are full of vitamins \& minerals. One must also include good herbs in their food like Amla which are cool in nature as their use will help the body in keeping strong appetite, itself healthy \& maintain its temperature.

Night regimen: At nights, one should sleep in the comfortable atmosphere in cool environment but it dosen't mean to sit in $\mathrm{AC}$ as it is harmful for health. Sexual activities must be avoided, people should wear very light and cotton cloths so as to remain comfortable \& sleep with ease.

Recommended herbs need to be taken during this period: Haldi and Neem.

Recommended Ayurvedic medicines: Livclear Herbal powder, Livclear capsules, Livclear syrup, Triyog Herbal Powder \& capsules, Nervocare capsules, Ayurvit capsules \& Arthro-rid capsules.

\section{Varsha ritucharya}

In rainy season, the agni (digestive activity) is weak. It is already debilitated by summer; it undergoes further decrease and gets vitiated by the Doshas. The Doshas get aggravated by the effect of thick clouds full of water, cold wind having snow, dirty water because of rain, warmth of the earth and sourness. Due to the poor strength of digestive activity, the Doshas start vitiating one another and cause many diseases. Hence, all general measures to mitigate imbalanced Doshas and to improve digestive activity should be adopted. One should undergo Panchakarma therapies \& administered asthapana basti (decoction enema therapy). One should use old grains for food, meat juice processed with spices etc., soup of pulses, wine prepared from grapes and fermented decoctions, which are old or mastu (whey, thin water or curds) processed with more of Sochal salt and powder of panchakola, should be used. Well boiled \& filtered water should be used for drinking. On days of no sunlight at all, the food should predominantly sour, salty and unctuous, dry, mixed with honey and easily digestible. Person should not move about on foot (move only on vehicles) should use perfumes, expose his clothes to fragrant fumes, dwell in upper stories of the house, devoid of heat, cold and snow.

a. Avoi: River water, beverage prepared with flour of corns mixed with ghee, daytime sleeping, sexual indulgence, exertion and exposure to Sun.

b. Recommended Ayurvedic medicines: Khadirarishta, Ashwagandhadi Churan, Mahamanjishtha Kwath, Saraswatarishta, Mrit Sanjeevani Sura \& Dashmoolarishta.

\section{Sharath Ritucharya}

The person becomes accustomed to the cold of rainy season. When he gets suddenly exposed to the warm rays of Sun, the Pitta, which has undergone increase in Varsha (rainy season) becomes greatly aggravated during sharath (autumn). In order to get over it, Tikta ghrita (medicated ghee recipe described in the treatment of kustha chapter 19 of Chikitsa sthana), purgation therapy and Mokshana (blood letting) should be resorted to. When hungry, the person should take foods which are of bitter, sweet and astringent tastes, and easily digestible such as Rice, green gram, sugar, Amla, Patola, honey and meat of animals of desert-like lands. The importance of this season is that Sharath is also the period of Ritusandhi like Vasanth when the weather changes. It becomes necessary for our body to adopt itself to the new conditions. That's why Hindu Navratras \& even Muslim's Rmzan comes during this period and fasting is done. Scientific reason behind it is that body needs detoxification \& cleansing this time. Fire element increases this time, temperature is already increasing which leads to increased Pitta. Old Pitta is already accumulated during the whole year need to be removed from the body \& it is done through Virechan (Panchkarma therapy). Snehpan is also done to mitigate the increased Pitta. That's why now a days, so many people have the problem of Gall Bladder Stones which happens due to Improper use of Pitta stored in excess. People also face the problems of Hyperacidity, Gas, Bloating, Indigestion \& Constipation. For all these things, proper detoxification \& cleansing of the body is very necessary through herbal medicines \& Panchkarma therapies.

a. Recommended ayurvedic medicines: Livclear Herbal powder, Livclear capsules, Livclear syrup, Respocare Herbal Powder, Respocare syrup, Nervocare capsules, Ayurvit capsules, Arthro-rid capsules, Body massage oil \& Joint Pain Oil. All the above mentioned herbal medicines \& Panchkarma treatments are easily available at Deep 
Ayurvedic Clinic in Kharar (Mohali), Chandigarh. Deep Ayurveda Clinic is also famous for their treatment of chronic diseases. We have the team of expert ayurvedic doctors and all the medicines are self manufactured after long clinical research and clinical trial at our own ayurvedic clinics and ayurvedic hospitals.
Acknowledgment

None.

Conflict of interest

None. 